\title{
Ellipsis
}

2021

\section{Unum de Multis}

Michelle Antoinette

University of New Orleans, New Orleans

Follow this and additional works at: https://scholarworks.uno.edu/ellipsis

\section{Recommended Citation}

Antoinette, Michelle (2021) "Unum de Multis," Ellipsis: Vol. 46 , Article 6.

DOI: https://doi.org/10.46428/ejail.46.06

Available at: https://scholarworks.uno.edu/ellipsis/vol46/iss1/6

This Poetry is brought to you for free and open access by the Department of English and Foreign Languages at ScholarWorks@UNO. It has been accepted for inclusion in Ellipsis by an authorized editor of ScholarWorks@UNO.

For more information, please contact scholarworks@uno.edu. 
Whether you are Chaldea, or over those deserts, Egypt, glimpse us beside the Milky Way alight. Within our wobbling orbits, we're rerouting age-old myths. Quiet, fire hot.

We've watched sisters swell with bliss. Eclipse for Sirius B. Cygnus made a love called Supernova. A mortal rendered her Eve. You think

you float beyond such scorched horizons, but you grasp mere reflections for sight. Know this: Your globe will frizzle as we are gathering worlds. After all

stones are small and sinking. You conceive positions, the heavens, give names, imagining fixed systems-

we draw

nevertheless

near from far

and though we must end you mash with Sol, twist circles round Luna, and tap a Terrestrial tangoever ever after. 